\title{
Towards Combining Electrochemical Water Splitting and Electrochemical Disinfection
}

\author{
Djamel Ghernaout ${ }^{1,2 *}$, Noureddine Elboughdiri ${ }^{1,3}$ \\ ${ }^{1}$ Chemical Engineering Department, College of Engineering, University of Ha'il, Ha'il, Saudi Arabia \\ ${ }^{2}$ Chemical Engineering Department, Faculty of Engineering, University of Blida, Blida, Algeria \\ ${ }^{3}$ Chemical Engineering Process Department, National School of Engineering, Zrig Gabes, University of Gabes, Gabes, Tunisia \\ Email: ^djamel_andalus@hotmail.com
}

How to cite this paper: Ghernaout, D. and Elboughdiri, N. (2021) Towards Combining Electrochemical Water Splitting and Electrochemical Disinfection. Open Access Library Journal, 8: e7445.

https://doi.org/10.4236/oalib.1107445

Received: April 22, 2021

Accepted: May 25, 2021

Published: May 28, 2021

Copyright (C) 2021 by author(s) and Open Access Library Inc.

This work is licensed under the Creative Commons Attribution International License (CC BY 4.0).

http://creativecommons.org/licenses/by/4.0/

\section{(c) (i) Open Access}

\begin{abstract}
To produce hydrogen $\left(\mathrm{H}_{2}\right)$ and oxygen $\left(\mathrm{O}_{2}\right)$, electrolytic water splitting (EWS) emerges as one of the most encouraging techniques in which to harness intermittent renewable power sources and store the energy these provide as a clean-burning and sustainable fuel. Nevertheless, efficacious formation of $\mathrm{H}_{2}$ and $\mathrm{O}_{2}$ is of little usage if such products cannot be kept separate and there are major dares linked with preserving suitable separation between $\mathrm{H}_{2}$ and $\mathrm{O}_{2}$ during electrolysis driven by intermittent renewable sources. In this work, a short view of fresh advance in the field of decoupled electrolysis for water splitting is presented and the potential that this technique has for enabling a range of other sustainable chemical processes is explored. Between such chemical processes, electrochemical disinfection (ED) remains a great promise in disinfecting water. This work suggests the application of ED in the EWS compartment producing $\mathrm{O}_{2}$ besides the other compartment producing $\mathrm{H}_{2}$. Similarities between the two processes include that both of them use electric current for their realization. For the first one, $\mathrm{H}_{2}$ and $\mathrm{O}_{2}$ are produced separately in two cells. The suggested idea here is to use EWS device for producing $\mathrm{H}_{2}$ in one cell and producing $\mathrm{O}_{2}$ in the second cell in which water may be disinfected by the electric field application and the electric current passage. Disinfection efficiency would be enhanced by the presence of $\mathrm{O}_{2}$. Practical examinations have to be conducted to determine the best scheme in terms of dimensions and disinfection efficiencies.
\end{abstract}

\section{Subject Areas}

Chemical Engineering \& Technology

\section{Keywords}

Electrochemical Water Splitting (EWS), Decoupled electrolysis, Oxygen $\left(\mathrm{O}_{2}\right)$, 
Hydrogen $\left(\mathrm{H}_{2}\right)$, Electrochemical Disinfection (ED), Microorganisms (MOs)

\section{Introduction}

Now, fossil fuels (as coal, oil, and natural gas) stay the world's main sources of energy [1]. Nevertheless, greenhouse gases (like $\mathrm{CO}_{2}$ ) that are produced through burning such fuels are related to general temperature augmentation [2] [3], shrinking ice sheets [4], ocean acidification [5], and extreme weather events [6]. Because the pollution rate and global energy demand persist to augment [7] [8] [9], suggesting energy solutions that do not depend on fossil fuels remains of vital significance. Renewable energy sources (like wind, solar, and tidal energy) form the most encouraging of such clean energy solutions, even if they are irregular [10]. As a result, supplying directly power from such sources could not be related to meet immediate energy demands [11]. Consequently, a technique of storing the energy produced by such renewable sources is fundamental for dealing with renewably generated power [1].

In such circumstances, hydrogen $\left(\mathrm{H}_{2}\right)$ is frequently presented as an encouraging "carbon neutral" energy carrier (i.e., fuel) [1]. In this system, renewably formed electricity is employed to electrolyze water $\left(\mathrm{H}_{2} \mathrm{O}\right)$ to produce $\mathrm{H}_{2}$ and oxygen $\left(\mathrm{O}_{2}\right)$. The $\mathrm{O}_{2}$ could be let out to the atmosphere whereas the $\mathrm{H}_{2}$ is stored as a fuel. This $\mathrm{H}_{2}$ is later oxidized (either by burning or in a fuel cell) to regenerate $\mathrm{H}_{2} \mathrm{O}$ and to liberate energy. In fact, $\mathrm{H}_{2}$ is not a perfect fuel; however, it possesses several interesting features like its minimum poisoning, capacity to be transported safely over long distances via pipeline [12], and its elevated energy density per unit mass (three times bigger than that of gasoline) [13]. Further, sustainably sourced $\mathrm{H}_{2}$ may be utilized to decrease $\mathrm{CO}_{2}$ or nitrogen $\left(\mathrm{N}_{2}\right)$ from the atmosphere to form carbon-neutral fuels and commodity chemicals (like hydrocarbons and ammonia). In several viewpoints, $\mathrm{H}_{2}$ could be adopted as the solution to a sustainable energy cycle [1].

This work suggests a short view of fresh advance in the field of decoupled electrolysis for water splitting is presented and the potential that this technique has for enabling a range of other sustainable chemical processes is explored. Between such chemical processes, electrochemical disinfection (ED) remains a great promise in disinfecting the air, water, and special surfaces of different nature such as drinking water, wastewater, pool water, and other water qualities or surfaces. An obvious direction on engineering details is intended especially those related to research on complex liquid systems, consideration of hazards observed from disinfection by-product generation, and interest to ameliorate cell design and disinfection technology. More interest is accorded to hybrid techniques to inspire originality, to utilize synergistic effects and to satisfy the needs of real system treatment under practical circumstances. This work suggests the application of ED in the EWS compartment producing $\mathrm{O}_{2}$ besides the other compart- 
ment producing $\mathrm{H}_{2}$.

\section{Electrochemical Water Splitting (EWS)}

\subsection{Electrochemical Storage of Renewable Energy}

Electrolyzing water could be viewed in matter of its two half-reactions: the hydrogen evolution reaction (HER) and the oxygen evolution reaction (OER) [1]. Such half-equations vary slightly following the $\mathrm{pH}$ at which the electrolysis is performed. At low $\mathrm{pH}$, the HER and OER proceed as follows (all potentials are vs. the standard hydrogen electrode, SHE):

$$
\begin{gathered}
2 \mathrm{H}^{+}+2 \mathrm{e}^{-} \rightarrow \mathrm{H}_{2} \quad \operatorname{HER}\left(\mathrm{pH}=0, \mathrm{E}^{0}=0.00 \mathrm{~V}\right) \\
2 \mathrm{H}_{2} \mathrm{O} \rightarrow \mathrm{O}_{2}+4 \mathrm{H}^{+}+4 \mathrm{e}^{-} \quad \text { OER }\left(\mathrm{pH}=0, \mathrm{E}^{0}=1.23 \mathrm{~V}\right)
\end{gathered}
$$

While, below alkaline circumstances, the half-reactions take place

$$
\begin{array}{cc}
4 \mathrm{OH}^{-} \rightarrow \mathrm{O}_{2}+2 \mathrm{H}_{2} \mathrm{O}+4 \mathrm{e}^{-} & \mathrm{OER}\left(\mathrm{pH}=14, \mathrm{E}^{0}=0.40 \mathrm{~V}\right) \\
4 \mathrm{OH}^{-} \rightarrow \mathrm{O}_{2}+2 \mathrm{H}_{2} \mathrm{O}+4 \mathrm{e}^{-} & \mathrm{OER}\left(\mathrm{pH}=14, \mathrm{E}^{0}=0.40 \mathrm{~V}\right)
\end{array}
$$

As a result, there is an important electrical energy demand to operate $\mathrm{H}_{2} \mathrm{O}$ electrolysis [1]. In the ordinary circumstances, a potential difference of $1.23 \mathrm{~V}$ is the thermodynamic minimum requested to electrolyze $\mathrm{H}_{2} \mathrm{O}$. Nevertheless, to conquer different kinetic and resistance barriers (and thus to operate considerable currents to flow for the OER and HER), more voltage is needed. Such supplementary voltage is known as overpotential that is a sum of the various additional potentials relating to concentration, ohmic resistances in the electrolyzer, and to the kinetic overpotentials for the individual HER and OER half-reactions [14]. One from the previous overpotentials, the overpotential demand for the OER has a tendency to control because the formation of $\mathrm{O}_{2}$ is a kinetically demanding four-electron, four-proton process [15] [16]. As a result, the OER is frequently viewed as the major kinetic bottleneck for the electrolytic production of $\mathrm{H}_{2}$ from $\mathrm{H}_{2} \mathrm{O}$ [1].

\subsection{From Traditional to Decoupled Electrolysis}

Water electrolysis happens below the effect of a direct current between two electrodes in a single cell [1]. Such crude form furnishes numerous disadvantages, the most undesirable of which remains the absence of isolation of the formed $\mathrm{H}_{2}$ and $\mathrm{O}_{2}$. As seen in Reactions (1)-(4), two moles of $\mathrm{H}_{2}$ are produced for every mole of $\mathrm{O}_{2}$ formed. Such gas-evolving reactions take place together, possibly generating a highly explosive mixture [17]. Industrially, this is avoided by employing membranes (or diaphragms) that isolate the compartment into anodic and cathodic cells. Big scale water electrolysis at high $\mathrm{pH}$ is performed utilizing a liquid alkaline electrolyte (concentrated aqueous $\mathrm{KOH}$ solution), at moderate temperatures $\left(20^{\circ} \mathrm{C}-80^{\circ} \mathrm{C}\right)$ with an asbestos diaphragm [18]. In such context, the anodic and cathodic pressures should be carefully regulated to prohibit gas 
permeation across the separator [19] [20] [21]. Great advance has been lately noted in fabricating solid polymer membrane electrolyzers in which an anion or proton exchange membrane (like Nafion) is utilized within a compressed cell stack [22] [23]. Even if comparatively costly, such cell designs could work at considerable pressure differentials, at outstanding running current densities, and without the necessity of caustic electrolytes. In such devices, the product streams are preserved separate, as gas crossover rates across the membranes are low [18] [21] [24].

The problem of separating the $\mathrm{H}_{2}$ and $\mathrm{O}_{2}$ of electrolysis begins to be more complicated when utilizing renewable energy sources, where the power inputs are usually variable and/or low [1]. In these situations, the low current densities that are reached correspond to low rates of gas formation. Further, such rates of gas generation could in turn start to attain the rates of gas crossover for some membranes, potentially leading to safety problems. A current density of 100 $\mathrm{A} / \mathrm{m}^{2}$ is adopted as a useful benchmark for solar-driven electrolyzers, since this is the approximate current density expected of a water splitting device operating at $10 \%$ solar-to-fuels efficiency under "1 Sun" illumination (AM 1.5, $100 \mathrm{~mW}$ / $\mathrm{cm}^{2}$ ) [25]. In such context, crossover of $\mathrm{H}_{2}$ into the anodic cell would be a real probability and may be mostly dangerous, because the lower explosion limit of $\mathrm{H}_{2}$ in $\mathrm{O}_{2}$ is only $4 \mathrm{~mol} \% \mathrm{H}_{2}$ in $\mathrm{O}_{2}$ [26] [27] [28]. Moreover, although effective and safe gas separation may be obtained, any solar-to-hydrogen apparatus, in which the half-reactions of water splitting stay coupled (like in a traditional electrolyzer, as shown Figure 1), will be subjected to the fact that the rate of the comparatively easy HER would remain be restricted by the more sluggish OER. In such scenario, harnessing low pressures of $\mathrm{H}_{2}$ gas safely and efficiently from large solar-to-hydrogen arrays is nontrivial and stays an unsolved dare.

To this objective, fresh progresses have been observed to "decouple" such processes utilizing redox mediators [1]. Indeed, a mediator with a suitable redox potential could be used such that the OER is coupled with the reduction of the mediator, rather than the direct formation of $\mathrm{H}_{2}$. Likewise, the HER can be realized independently of the OER, via coupling $\mathrm{H}_{2}$ production to the re-oxidation of the mediator, rather than to water oxidation (Figure 1). With each half-reaction taking place separately, the HER could be performed at much enhanced rates

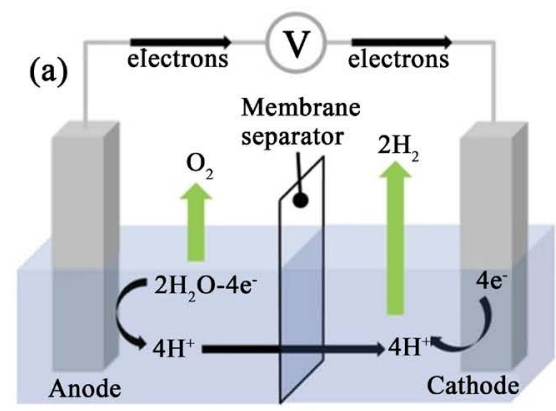

Conventional (coupled) water electrolysis

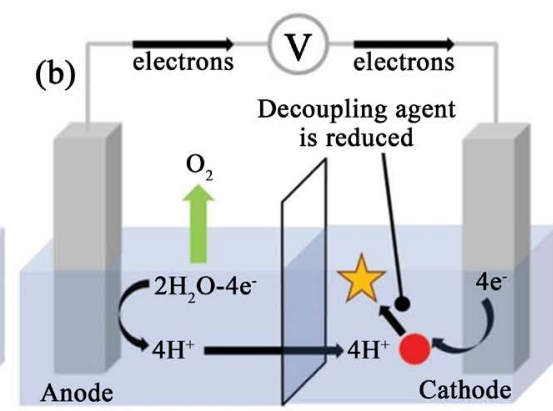

Decoupled water electrolysis: oxygen evolution

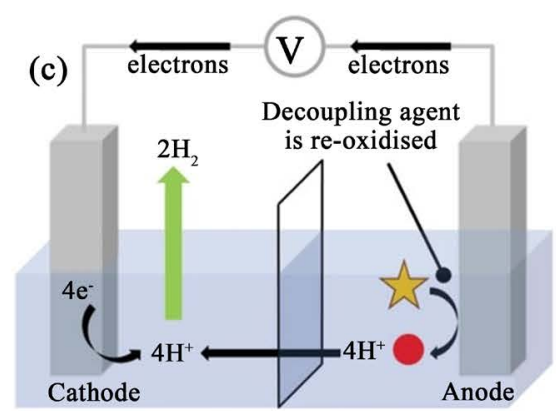

Decoupled water electrolysis: hydrogen evolution

Figure 1. Conventional (a) vs. decoupled ((b), (c)) water electrolysis under general acidic conditions [1]. 
compared to that feasible in traditional water electrolysis. Further, the possibility to carry out the HER and OER both in different spaces ("spatial separation") and at different times ("temporal separation") considerably enhances flexibility for harvesting $\mathrm{H}_{2}$ efficiently and safely and greatly decreases the demand for any gas purification stages. The features requested of a suitable mediator are stability in both the oxidized and reduced forms and a reversible redox couple with a potential that resides between the onset potentials of the OER and HER. Consequently, decoupled electrolysis could be described as any process where the ultimate anodic and cathodic products of electrolysis are formed under at least one of the next situations: 1) at rates that are not intrinsically related to each other, 2) at different times to each other, or 3) in entirely different electrochemical cells to each other (Figure 2).

Since its beginning during 2013 [29], the field of decoupled electrolysis has progressed rapidly. However, few short reviews have been devoted to the subject to date. The first one being a short discussion by Wallace and Symes [30], the second being a short section in larger overview on water electrolysis by You and Sun [31] and the third a short review by Liu et al. [32]. McHugh et al. [1] presented a thorough discussion of this thrilling field, highlighting the opportunities for decoupled electrolysis in energy storage, energy conversion, and chemical synthesis.

(b)

(a)
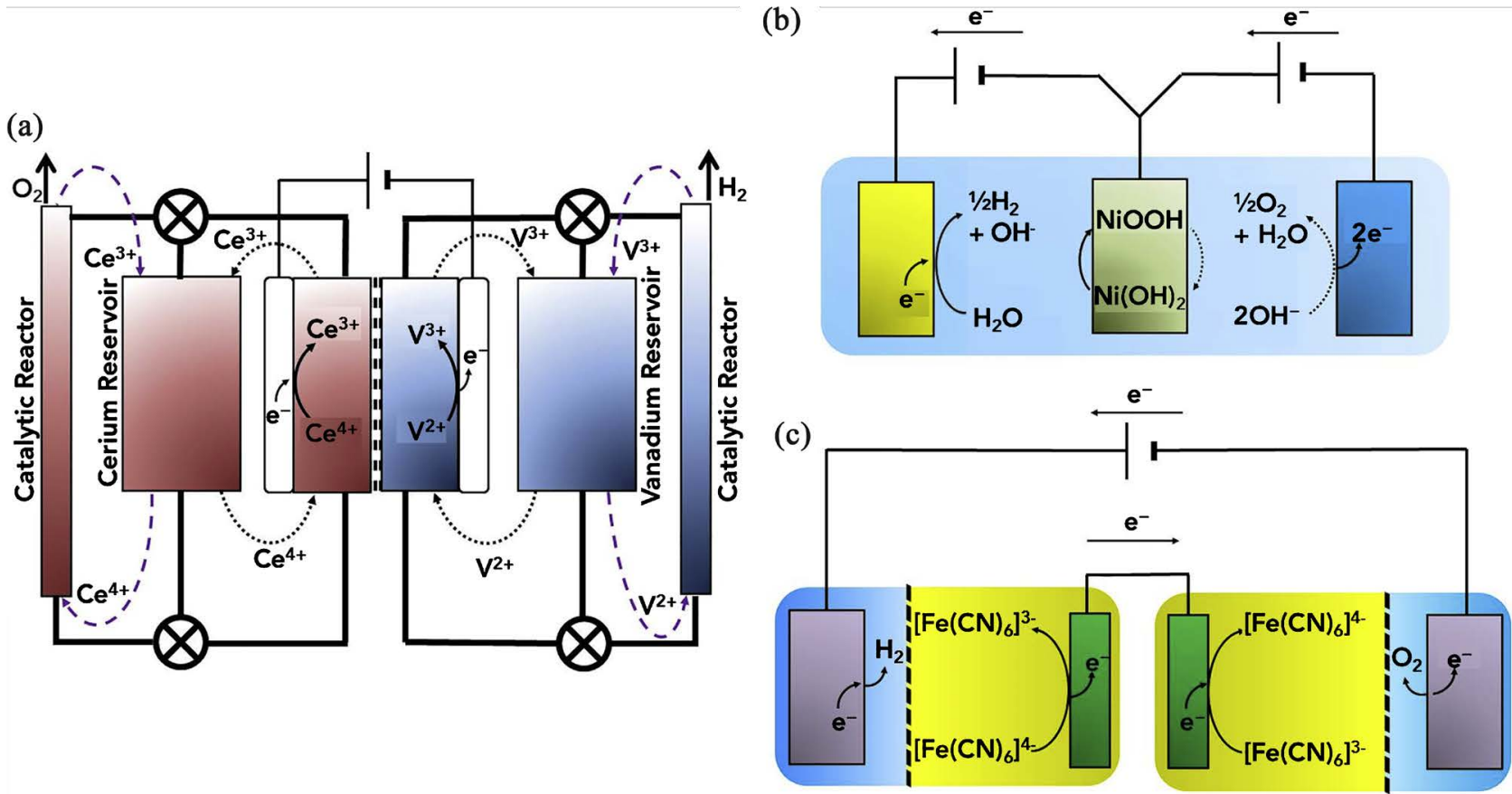

Figure 2. Alternative decoupling strategies. (a) Girault's dual-circuit vanadium-cerium flow system for flexible hydrogen production or energy storage. Purple dashed lines show the chemical discharge route via $\mathrm{O}_{2}$ and $\mathrm{H}_{2}$ while black dotted lines correspond to operation as a redox flow battery. (b) Decoupled water electrolysis using nickel (oxy) hydroxides as a solid-state redox mediator. (c) Walsh's bipolar electrode strategy for decoupled electrolysis. Two outer Pt electrodes (gray) drive the water-splitting half-reactions in two separate cells, where electrical and electrochemical contact is maintained via the ferricyanide redox couple and the two carbon electrodes (green) connected by a wire [30]. 


\subsection{Decoupled Electrochemical Water Splitting (EWS): Dares \& Perspectives}

In their discussion, McHugh et al. [1] presented the present state-of-the-art in decoupled electrolysis for water splitting, following the development of the field from its conceptualization in 2013 through to the several refinements of decoupled electrolysis that have since been improved [1]. During this march, crucial stages have been realized. Such steps comprised 1) the proof of solar-driven $\mathrm{H}_{2}$ generation employing decoupling techniques, 2) the invention of decoupling agents that could be involved to carry out one of the half-reactions of water splitting spontaneously (such as through manipulation of the temperature or via convenient selection of electrodes and/or catalysts), 3) the expansion of robust solid-state decoupling agents, 4) the conjunction of decoupling techniques with bipolar electrolysis, and 5) the implementation of decoupling techniques to reactions beyond water splitting (like coupling $\mathrm{H}_{2}$ generation with organic upgrading oxidation reactions or carrying out organic hydrogenation reactions utilizing protons and electrons obtained from water). In addition, decoupling could be utilized both for electrolytic processes (i.e., those needing a net energy input like water splitting) and galvanic processes (where spontaneous chemical reactions are harnessed to generate electrical power like in fuel cells).

However, numerous decisive dares stay in the expansion of decoupled electrolysis in terms of device complexity and overall system stability. In terms of the second, materials compatibility among the decoupling agents and different cell components (such as membrane separators) and the stability of the agents themselves to repeated redox cycling frequently stay unproven. This is attributed mostly to a shortage of information on the long-term efficiency of decoupled systems. Viable information on long-term system stability has to be acquired before commercial usages become certain. For the present, decoupled electrolysis systems frequently give rise to augmented demands for extra balance of plant (and thus require bigger complexity) contrasted to easier, coupled approaches [1].

\section{Electrochemical Disinfection (ED)}

\subsection{Presentation and Descriptions}

Electrochemical disinfection (ED) may be viewed as a physicochemical technology of disinfecting water via applying electrochemistry [33] [34] [35]. ED is generally a small-scale technique applied decentralized [36] [37] [38]. Disinfectant formation and distribution inside water could be realized discontinuously or continuously in flow-through mode or as chemicals' injection to the devices from storage tanks [39] [40] [41]. Such technology is viewed as being sophisticated, not difficult to command, and avoiding storage and handling of toxic chemicals [42] [43] [44].

ED is generally founded on the oxidation power of disinfectants in the electrode layer or the bulk of electrolytes [45] [46]. Usually, harm to the intracellular 
enzyme system is referred to as the major cause for demobilizing microorganisms (MOs) [47] [48] [49]. According to Bergmann [33], electrical field contributions and $\mathrm{pH}$-based impact could be disregarded in most ED situations. Several authors [50] [51] [52] [53] found that ED process, especially in the case of electrocoagulation (EC) [54] [55] [56], is greatly dependent on electric field and $\mathrm{pH}$.

Pulsed electrical field technique, moderate electrical field handling, ohmic heating, plasma-related water treatment [57] [58], and ship body cleaning using conductive paintings are classified as special electrical field management and not discussed here [33].

MOs could as well be neutralized at relatively low electrode potentials in electron exchange reactions when they are closely adsorbed to electrodes [59] [60] [61]. Such technique remains time-consuming and not effective [33]. The more recent method is that of adsorbing MOs integrated with electrochemical oxidation [49] [62] [63]. At bigger potentials, oxidation and neutralizing of fixed MOs are likely if radicals are formed by electrodes possessing bigger oxygen overvoltage [64] [65] [66].

The function of direct oxidation by hydroxyl radicals $\left({ }^{\bullet} \mathrm{OH}\right)$ is frequently lower than anticipated. This is may be related to short radical lifetime, reaction competition, and when a relatively small number of MOs is adsorbed at the electrode [33] [67].

In the situation of gas (i.e., $\mathrm{H}_{2}$ from cathode and $\mathrm{O}_{2}$ from anode) production, MOs could be physically eliminated from the water (i.e., electroflotation [68] [69]) and electrode surfaces [33] [70].

The plurality of disinfectant-producing methods may be performed in water, the synthesis of ferrates as powerful oxidants could be carried out in a molten electrolyte or in water [71] [72] [73] [74].

\subsection{Usual Killing Agents Encountered in Electrochemical Disinfection (ED) Device}

Killing agents may be produced via anodic reactions and rarer in cathodic reactions [33]. Table 1 lists the most important of them.

\subsection{By-Product Troubles}

As in chemical disinfection, taking into account by-products formation in ED is more and more imposed [98] [99] [100]. Table 2 summarizes by-product categorization [33].

\subsection{Cell Designs}

Cell geometries could be categorized in separator-divided or undivided cells with immersed electrodes, parallel plate electrodes, 3D-flow-by and flow-through electrodes, rods, and tubular electrodes in monopolar, bipolar, or mixed arrangement [75]. Lately, a multicylindrical cell design was announced, possessing six 
Table 1. Disinfectants formed in an ED apparatus [33].

\begin{tabular}{|c|c|}
\hline Disinfectant & Description \\
\hline Chlorine & $\begin{array}{l}\text { For } \mathrm{Cl}_{2} \text {-founded } \mathrm{ED} \text {, fresh tendencies were noted to substitute pressurized } \mathrm{Cl}_{2} \text { with chlorine containing solutions formed via } \\
\text { electrochemical technology [75] [76] [77], frequently running at } \mathrm{Cl}^{-}<1 \mathrm{~g} / \mathrm{L} \text {. Chlorine species mixture could include dissolved } \\
\text { chlorine }\left(\mathrm{Cl}_{2, \text { dis }}\right) \text {, hypochlorous acid (HOCl), and hypochlorite ions }\left(\mathrm{OCl}^{-}\right) \text {jointly known as free active chlorine. Inorganic } \\
\text { chloramines may be included in the bonded active chlorine and are viewed as undesirable by-products, as well as organic } \\
\text { chloramines [78] [79] [80]. The simple and cost-effective anodic production, storability, and long-term residual effect } \\
\text { interpret the excellent significance of } \mathrm{Cl}_{2} \text {-founded disinfection until now [81]. The technology is common and mostly } \\
\text { employed in potable water disinfection, swimming pool water and seawater treatment [82] [83]. Supplementary disinfecting } \\
\text { power may be attributed to another component, dichlorine monoxide }\left(\mathrm{Cl}_{2} \mathrm{O}\right) \text { [84], even if additional investigation remains } \\
\text { required. }\end{array}$ \\
\hline $\begin{array}{l}\text { Chlorine dioxide } \\
\qquad\left(\mathrm{ClO}_{2}\right)\end{array}$ & $\begin{array}{l}\text { The progressive replacement of } \mathrm{Cl}_{2} \text { as a disinfectant is more and more pronounced [85] [86] [87]. Chlorine dioxide }\left(\mathrm{ClO}_{2}\right) \\
\text { forming fewer by-products and odor has been adopted in such approach [77]. Electrochemically, } \mathrm{ClO}_{2} \text { could be formed onsite } \\
\text { using undivided electrochemical or divided 2- or 3-compartment cells by anodic chlorite oxidation or cathodic chlorate } \\
\text { reduction, ore from both processes [33] [88] [89]. At the commercial level, small cells having ion-exchange membranes have } \\
\text { been proposed. The starting chlorite solution is in the domain of } \mathrm{g} / \mathrm{L} \text { concentration. } \mathrm{ClO}_{2} \text { is formed in the } \mathrm{g} / \mathrm{h} \text { domain with } \\
\text { performances bigger than } 80 \% \text { at } \mathrm{pH} 4-6 \text {. Bergmann [33] suggested two procedures of generating } \mathrm{ClO}_{2} \text { for surface } \\
\text { disinfection via adding scavengers to the chlorite solution at } \mathrm{mg} / \mathrm{L} \text { level domain. Under regulated parameters, total efficiencies } \\
\text { could be attained in undivided cells [33]. For instance, when a chlorite solution is mixed with ozone solutions (formed } \\
\text { electrochemically or by silent discharge) [90], a defined molar ratio exists, conducting to nearly complete chlorite-to-chlorine } \\
\text { dioxide conversion (Figure 3). In such situation, a scavenger avoids secondary reactions of the intermediate } \mathrm{O}_{3}^{-} \text {. }\end{array}$ \\
\hline Ozone $\left(\mathrm{O}_{3}\right)$ & $\begin{array}{l}\text { It was ultramodern to generate ozone }\left(\mathrm{O}_{3}\right) \text { on } \mathrm{PbO}_{2} \text {, Platinum, } \mathrm{SnO}_{2} \text {, and other anodes [91] [92]. Recent Boron Doped } \\
\text { Diamond (BDD) anodes in divided cells are more performant, furnishing } \mathrm{O}_{3} \text { at bigger levels and formation rates of } 10^{-4}-10^{-3} \\
\mathrm{~g} / \mathrm{h} \cdot \mathrm{cm}^{2} \text { [93]. The credible onsite analysis of single oxidants inside a combination of } \mathrm{O}_{3} \text { and different oxidants stays an } \\
\text { unsolved difficulty. }\end{array}$ \\
\hline $\begin{array}{c}\text { Hydrogen } \\
\text { peroxide }\left(\mathrm{H}_{2} \mathrm{O}_{2}\right)\end{array}$ & $\begin{array}{l}\text { Methods employing oxygen-reducing cathodes could lead to } \sim 2 \% \text { (weight) } \mathrm{H}_{2} \mathrm{O}_{2} \text { : } \\
\mathrm{O}_{2}+2 \mathrm{H}^{+}+2 \mathrm{e}^{-} \rightarrow \mathrm{H}_{2} \mathrm{O}_{2} \text { (5) } \\
\text { This is much more juxtaposed to the anodic formation of two hydroxyl radicals on noncatalytic BDD pursued by their } \\
\text { reaction to } \mathrm{H}_{2} \mathrm{O}_{2} \text {. Reaction between } \mathrm{OCl}^{-} \text {and } \mathrm{H}_{2} \mathrm{O}_{2} \text { could lead to singlet and triplet oxygen production [94]. }\end{array}$ \\
\hline Others & $\begin{array}{l}\text { Additional disinfectants and technologies may be noted such as peroxodisulfate [95] [96], chloramination [97], bromine, and } \\
\text { ferrates [35] [39] [71] even if without large industrial use. }\end{array}$ \\
\hline
\end{tabular}

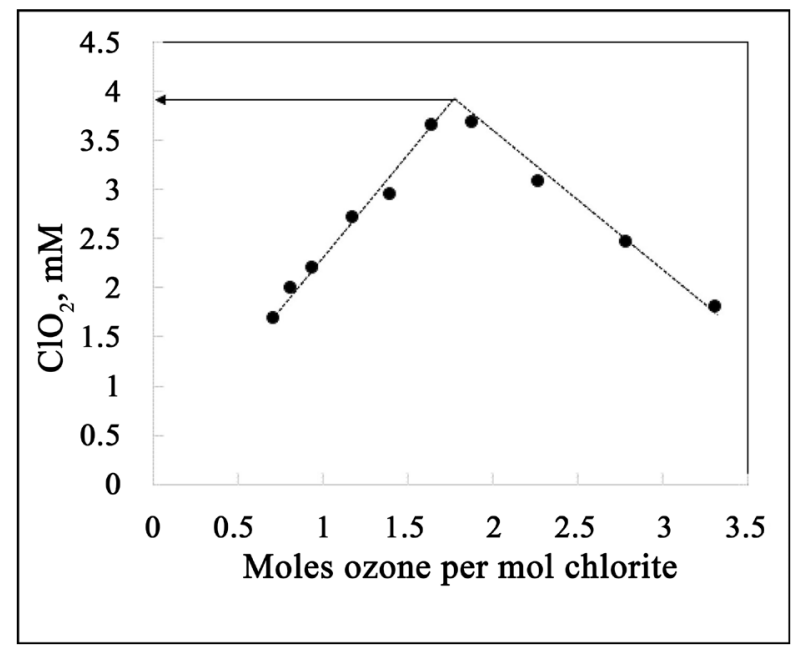

Figure 3. Generation of $\mathrm{ClO}_{2}$ (recalculated) obtained from reacting different volumes of $0.5 \mathrm{mM}$ ozone solution with $3.9 \mathrm{mM}$ chlorite solution at $5^{\circ} \mathrm{C}$, scavenger ethanol, and analysis by UV spectroscopy. The maximum reveals that nearly all chlorite can be converted to $\mathrm{ClO}_{2}[33]$. 
Table 2. By-product classification [33].

\begin{tabular}{|c|c|}
\hline By-product class & Description \\
\hline $\begin{array}{c}\text { Electrolysis } \\
\text { By-Products } \\
\quad(E B P s)\end{array}$ & $\begin{array}{l}\text { Electrolysis by-products (EBPs) are the consequence of undesirable } \\
\text { electrochemical reactions such as the anodic chlorate and the cathodic nitrite } \\
\text { and ammonia formation [101]: } \\
6 \mathrm{HClO}+3 \mathrm{H}_{2} \mathrm{O} \rightarrow 2 \mathrm{ClO}_{3}^{-}+4 \mathrm{Cl}^{-}+12 \mathrm{H}^{+}+3 / 2 \mathrm{O}_{2}+6 \mathrm{e}^{-}(6) \\
\mathrm{NO}_{3}^{-}+\mathrm{H}_{2} \mathrm{O}+2 \mathrm{e}^{-} \rightarrow \mathrm{NO}_{2}^{-}+2 \mathrm{OH}^{-}(7) \\
\mathrm{NO}_{2}^{-}+5 \mathrm{H}_{2} \mathrm{O}+6 \mathrm{e}^{-} \rightarrow \mathrm{NH}_{3}+7 \mathrm{OH}^{-} \text {(8) }\end{array}$ \\
\hline $\begin{array}{c}\text { Disinfection } \\
\text { By-Products } \\
\quad(D B P s)\end{array}$ & $\begin{array}{l}\text { As portion of electrolytes, organic matter is mainly classified as Natural Organic } \\
\text { Matter (NOM) [102] [103] [104], Total Organic Carbon (TOC) [105] [106] } \\
\text { [107], and Dissolved Organic Carbon (DOC) [108] [109] [110]. They are typical } \\
\text { precursors for the famous "Disinfection By-Products (DBPs)" [110] [111] [112]. } \\
\text { Familiar from chemical disinfection [113] [114] [115], DBPs are generated from } \\
\text { reacting disinfectants with pollutants present in water [116]. In ED for drinking } \\
\text { water, identical DBPs were detected when juxtaposed to chemical chlorination } \\
\text { [53] [116] [117]. Reacting pathogen cell mater could be a supplementary source } \\
\text { of DBPs (Figure 4) [118] [119] [120]. }\end{array}$ \\
\hline
\end{tabular}

Reaction Reaction By-Products (RBPs) constitute all residual reactions in the electrode By-Products layers and bulk of solution. As an illustration is the chemical chlorate generation $(R B P S) \quad$ from free active chlorine species or from chlorite ions [118].

(a)

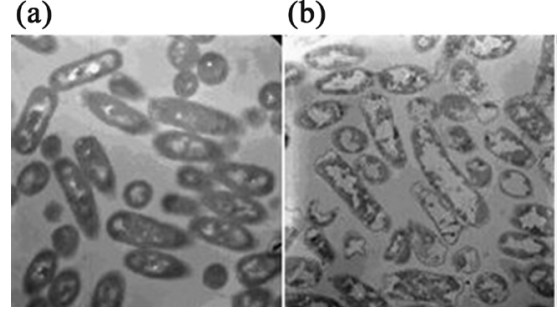

(c)

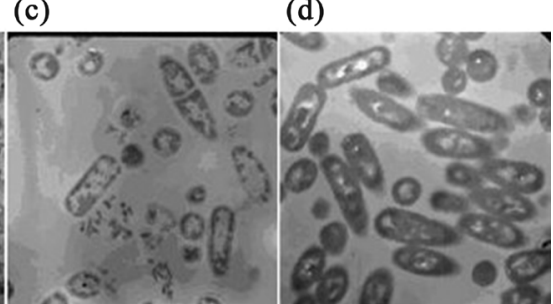

Figure 4. Cross section of embedded MOs before treatment and after treatment with $\mathrm{H}_{2} \mathrm{O}_{2}$ and active $\mathrm{Cl}_{2}$ from electrolysis. The starting concentrations and treatment times are indicated: (a), Escherichia coli untreated sample, $1 \times 10^{8}$ colony forming units $(\mathrm{CFU}) / \mathrm{mL}$; (b), E. coli, $1 \times 10^{8} \mathrm{CFU} / \mathrm{mL}, 3 \% \mathrm{H}_{2} \mathrm{O}_{2}, 1 \mathrm{~min}$; (c), Bacillus subtilis, $1 \times 10^{8}$ $\mathrm{CFU} / \mathrm{mL}, 7.5 \% \mathrm{H}_{2} \mathrm{O}_{2}, 120 \mathrm{~min}$; (d), E. coli, $1 \times 10^{8} \mathrm{CFU} / \mathrm{mL}, 19 \mathrm{ppm} \mathrm{Cl}, 120 \mathrm{~min} \mathrm{[118].}$

cylindrical graphite electrodes [121]. Diverse innovation divulges from literature on suggesting 3D-BDD foam electrodes [33] [122] [123].

Mesh-like electrode structures are also developed [124] [125]. Recently, 3D activated carbon electrodes are exemplary for the mostly 2-step technique of electro-adsorption [33].

\subsection{Mathematical Modeling}

In applied electrochemistry, mathematical modeling emerged since several decades [33]. Now, strong simulation programs are accessible. Relating to ED implementations, the next usual modeling targets could be practically categorized: 1) quantification of disinfection findings concerning disinfectant formation and decomposition [126] [127], 2) current density distribution for reducing cell voltage [128], 3) averting electrode deterioration and by-product formation [33], 4) quantification of non-ideal flow behavior and, 5) assessment of probable reac- 
tion paths [129], etc.

\subsection{Perspectives}

In latest ED investigation, three main trends could be recognized: 1) augmented attempts in study for by-products and their likely poisoning, 2) application of fresh materials, frequently at the nanoscale [130], 3) process integrations/design of hybrid ED techniques [33] [131].

In electrochemical engineering, amelioration of electrode materials in terms of structure, yield, lifetime, and different indicators remains a main objective. Indeed, material issues concerning assistive, pre-treatment and post-treatment methods are more and more discussed as illustrated in nanotechnology-based electrode structuring [96] [124] [132], filter selectivity improvement [33] [133], and for numerous additional technology components.

Inventions are foremost related to hybrid processes [33]. For wastewaters [134] [135], adopting the direct ED is not suitable due to an uncontrolled reaction scheme with unknown intermediates and final products [136] [137] [138]. This is why coupling single treatment methods to integrated ones, as typical for Advanced Oxidation Processes (AOPs) [63] [64] [139], has been adopted [49] [61] [62].

Individual processes could be integrated in a minimum of two fashions: stepwise one after the other (in one or two devices), and combined into one (Table 3). As an illustration, in terms of by-product generation, it is logical to irradiate water in an initial stage and then, in a second stage, to treat using a chlorination method; in contrast, the irradiation of formerly chlorinated water could form

Table 3. Most important hybrid processes dealing with electrochemical disinfection (ED) [33].

\begin{tabular}{|c|c|}
\hline Hybrid processes & Description \\
\hline $\begin{array}{c}\text { Electrocoagulation } \\
(E C) / \text { Electro-Fenton }(E F)\end{array}$ & $\begin{array}{l}\text { Electrocoagulation (EC) process has the potential to kill pathogens efficiently and economically as the cost for } \\
\text { electrode materials (Fe, Al) are relatively minor [143] [144] [145]. Several researchers merged EC with other } \\
\text { techniques [146] [147] [148]. Other scientists juxtaposed EC to different techniques like Electro-Fenton (EF) } \\
\text { [33]. EF with an in situ formation of }{ }^{\bullet} \mathrm{OH} \text { is affiliated to AOPs and frequently proposed for treating wastewater } \\
\text { [139]. Comparatively to EC, researches depicted better disinfection impacts of the EF method [149] [150]. }\end{array}$ \\
\hline ED/filtration & $\begin{array}{l}\text { Filtration could be used with filters possessing defined pore size distribution as with nanopore-filters [151] [152] } \\
\text { [153]. This permits filtration of organic matter and MOs [154] [155]. If pursued by ED, disinfection performance } \\
\text { could be attained and by-product generation will be reduced. Supplementary adsorption after filtration may } \\
\text { ameliorate the yields [33]. Different original design is using reactive membranes [156] [157] [158]. } \\
\text { Membrane-integrated electrodes could participate to membrane disinfection from time to time or add } \\
\text { disinfecting species to the water flowing through [159] [160]. }\end{array}$ \\
\hline ED/adsorption & $\begin{array}{l}\text { High surfaces of adsorbing materials help them to adsorb MOs on uncharged or charged surfaces [161] [162]. In } \\
\text { reverse or changed electrode potential, MOs could be repulsed and electrochemically demobilized [163]. Last } \\
\text { essential functionality is once more the adsorption of products and by-products after a first-step ED procedure } \\
\text { [164]. }\end{array}$ \\
\hline ED/photocatalysis & $\begin{array}{l}\text { The semiconductor composition of Mixed Metal Oxide (MMO) electrode material makes it interesting for being } \\
\text { merged with irradiation (electro-photocatalytic disinfection [165] [166] [167]. Researchers examined usual } \\
\text { issues, concepts and tendencies [165] [166]. Scientists focused on efficiency estimation [167], usage of } \\
\text { nanomaterials and novel electrode design [33], disinfection by-products, and } \mathrm{Cl}_{2} \text { generation [33]. }\end{array}$ \\
\hline
\end{tabular}


more by-products. One more benefit is the reservoir effect that could not be attained by sole UV disinfection [140] [141] [142].

\section{A Bridge between Electrochemical Water Splitting (EWS) and Electrochemical Disinfection (ED)}

We have briefly discussed EWS and ED techniques. Similarities between the two processes include that both of them use electric current for their realization. For the first one, $\mathrm{H}_{2}$ and $\mathrm{O}_{2}$ are produced separately in two cells. Such gases may be produced in ED especially for electroflotation and EC processes. The suggested idea here is to use EWS device for producing $\mathrm{H}_{2}$ in one cell and producing $\mathrm{O}_{2}$ in the second cell in which water may be disinfected by the electric field application and the electric current passage. Disinfection efficiency would be enhanced by the presence of $\mathrm{O}_{2}$.

As shown previously, Figure 2 illustrates three alternative decoupling strategies. Configurations (a) and (b) (Figure 2) seem to be more suitable for producing $\mathrm{H}_{2}$ and $\mathrm{O}_{2}$ as well treating water. In Figure 2(b), decoupled water electrolysis using nickel (oxy)hydroxides as a solid-state redox mediator is presented; and in Figure 2(c), Walsh's bipolar electrode strategy for decoupled electrolysis is depicted.

\section{Conclusions}

To produce $\mathrm{H}_{2}$ and $\mathrm{O}_{2}$, electrolytic water splitting (EWS) emerges as one of the most encouraging techniques in which to harness intermittent renewable power sources and store the energy these provide as a clean-burning and sustainable fuel. Lately, this has conducted to an eruption in publications on EWS, most of them worked on increasing the productivity of the electrochemical reactions themselves. Decoupled electrolysis presents a solution to numerous of such dares through authorizing $\mathrm{O}_{2}$ and $\mathrm{H}_{2}$ to be formed at different times, at different rates, and even in completely different electrochemical cells. In this work, a short view of fresh advance in the field of decoupled electrolysis for water splitting is presented. On the other hand, ED remains a great promise in disinfecting water. This work suggests the application of ED in the decoupled electrolysis compartment producing $\mathrm{O}_{2}$ besides the other compartment producing $\mathrm{H}_{2}$. The main conclusions drawn are listed below:

1) During the last seven years, decoupled electrolysis for water splitting has known an outstanding expansion following the development of the field from its conceptualization [1]. Decoupling could be utilized both for electrolytic processes and for galvanic processes. However, numerous decisive dares stay in the expansion of decoupled electrolysis in terms of device complexity and overall system stability. In terms of the second, materials compatibility among the decoupling agents and different cell components and the stability of the agents themselves to repeated redox cycling frequently stay unproven. This is attributed mostly to a shortage of information on the long-term efficiency of decoupled systems. Via- 
ble information on long-term system stability has to be acquired before commercial usages become certain. For the present, decoupled electrolysis systems frequently give rise to augmented demands for extra balance of plant contrasted to easier, coupled approaches [1].

2) ED is very innovative and developing technology domain. Even with all advance noted in fundamental study, pilot investigations, and usage, the maturity for numerous disinfection techniques stays weak and some issues could not be managed such as [33]: a) ED processes remain not often famous; b) application circumstances require preliminary investigations for selecting optimally the disinfection devices and method, and for pre-treatment and post-treatment stages; c) strictest rules and demands occur in the potable water industry with limiting by-product concentration at $\mu \mathrm{g} / \mathrm{L}$ level span especially for highly-oxidative anodes and; d) fresh ED processes could be costly what renders them uncompetitive and restricts their diffusion.

3) We have briefly discussed EWS and ED techniques. Similarities between the two processes include that both of them use electric current for their realization. For the first one, $\mathrm{H}_{2}$ and $\mathrm{O}_{2}$ are produced separately in two cells. Such gases may be produced in ED especially for electroflotation and EC processes. The suggested idea here is to use EWS device for producing $\mathrm{H}_{2}$ in one cell and producing $\mathrm{O}_{2}$ in the second cell in which water may be disinfected by the electric field application and the electric current passage. Disinfection efficiency would be enhanced by the presence of $\mathrm{O}_{2}$. Practical examinations have to be conducted to determine the best scheme in terms of dimensions and disinfection efficiencies.

\section{Acknowledgements}

The Research Deanship of University of Ha'il, Saudi Arabia, has funded this research through the Project RG-20 113.

\section{Conflicts of Interest}

The authors declare no conflicts of interest regarding the publication of this paper.

\section{References}

[1] McHugh, P.J., Stergiou, A.D. and Symes, M.D. (2020) Decoupled Electrochemical Water Splitting: From Fundamentals to Applications. Advanced Energy Materials, 10, Article ID: 2002453. https://doi.org/10.1002/aenm.202002453

[2] Noyes, P.D., McElwee, M.K., Miller, H.D., Clark, B.W., Van Tiem, L.A., Walcott, K.C., Erwin, K.N. and Levin, E.D. (2009) The Toxicology of Climate Change: Environmental Contaminants in a Warming World. Environment International, 35, 971 986. https://doi.org/10.1016/j.envint.2009.02.006

[3] Cheng, L., Trenberth, K.E., Fasullo, J., Boyer, T., Abraham, J. and Zhu, J. (2017) Improved Estimates of Ocean Heat Content from 1960 to 2015. Science Advances, 3, e1601545. https://doi.org/10.1126/sciadv.1601545

[4] Shepherd, A., Ivins, E. and Rignot, E. (2018) Mass Balance of the Antarctic Ice Sheet 
from 1992 to 2017. Nature, 558, 219-222.

https://doi.org/10.1038/s41586-018-0171-6

[5] Doney, S.C., Fabry, V.J., Feely, R.A. and Kleypas, J.A. (2009) Ocean Acidification: The Other $\mathrm{CO}_{2}$ Problem. Annual Review of Marine Science, 1, 169-192.

https://doi.org/10.1146/annurev.marine.010908.163834

[6] Lindner, M., Maroschek, M., Netherer, S., Kremer, A., Barbati, A., Garcia-Gonzalo, J., Seidl, R., Delzon, S., Corona, P., Kolström, M., Lexer, M.J. and Marchetti, M. (2010) Climate Change Impacts, Adaptive Capacity, and Vulnerability of European Forest Ecosystems. Forest Ecology and Management, 259, 698-709. https://doi.org/10.1016/j.foreco.2009.09.023

[7] Ghernaout, D. (2017) Environmental Principles in the Holy Koran and the Sayings of the Prophet Muhammad. American Journal of Environmental Protection, 6, 7579. https://doi.org/10.11648/j.ajep.20170603.13

[8] Ghernaout, D. (2019) Greening Cold Fusion as an Energy Source for Water Treatment Distillation-A Perspective. American Journal of Quantum Chemistry and Molecular Spectroscopy, 3, 1-5.

[9] Irki, S., Kasbadji-Merzouk, N., Hanini, S. and Ghernaout, D. (2020) Modelling of the Coupling of Desalination Plants with the Thermal Solar Energy System. Water Supply, 20, 1807-1822. https://doi.org/10.2166/ws.2020.092

[10] Roger, I., Shipman, M.A. and Symes, M.D. (2017) Earth-Abundant Catalysts for Electrochemical and Photoelectrochemical Water Splitting. Nature Reviews Chemistry, 1, Article No. 0003. https://doi.org/10.1038/s41570-016-0003

[11] Styring, S. (2012) Artificial Photosynthesis for Solar Fuels. Faraday Discussions, 155, 357-376. https://doi.org/10.1039/C1FD00113B

[12] Wallace, J.S. and Ward, C.A. (1983) Hydrogen as a Fuel. International Journal of Hydrogen Energy, 8, 255-268. https://doi.org/10.1016/0360-3199(83)90136-2

[13] Sherif, S.A., Barbir, F. and Veziroglu, T.N. (2005) Wind Energy and the Hydrogen Economy-Review of the Technology. Solar Energy, 78, 647-660. https://doi.org/10.1016/j.solener.2005.01.002

[14] Xiang, C., Papadantonakis, K.M. and Lewis, N.S. (2016) Principles and Implementations of Electrolysis Systems for Water Splitting. Materials Horizons, 3, 169-173. https://doi.org/10.1039/C6MH00016A

[15] Lalvani, S.B. and Rajagopal, P. (1992) Lignin-Augmented Water Electrolysis. Journal of the Electrochemical Society, 139, L1. https://doi.org/10.1149/1.2069212

[16] Suen, N.-T., Hung, S.-F., Quan, Q., Zhang, N., Xu, Y.-J. and Chen, H.M. (2017) Electrocatalysis for the Oxygen Evolution Reaction: Recent Development and Future Perspectives. Chemical Society Reviews, 46, 337-365. https://doi.org/10.1039/C6CS00328A

[17] Das, L.M. (1996) Hydrogen-Oxygen Reaction Mechanism and Its Implication to Hydrogen Engine Combustion. International Journal of Hydrogen Energy, 21, 703715. https://doi.org/10.1016/0360-3199(95)00138-7

[18] Carmo, M., Fritz, D.L., Mergel, J. and Stolten, D. (2013) A Comprehensive Review on PEM Water Electrolysis. International Journal of Hydrogen Energy, 38, 49014934. https://doi.org/10.1016/j.ijhydene.2013.01.151

[19] Gahleitner, G. (2013) Hydrogen from Renewable Electricity: An International Review of Power-To Gas Pilot Plants for Stationary Applications. International Journal of Hydrogen Energy, 38, 2039-2061.

https://doi.org/10.1016/j.ijhydene.2012.12.010 
[20] Sommer, E.M., Martins, L.S., Vargas, J.V.C., Gardolinski, J.E.F.C., Ordonez, J.C. and Marino, C.E.B. (2012) Alkaline Membrane Fuel Cell (AMFC) Modeling and Experimental Validation. Journal of Power Sources, 213, 16-30. https://doi.org/10.1016/j.jpowsour.2012.03.089

[21] Chi, J. and Yu, H. (2018) Water Electrolysis Based on Renewable Energy for Hydrogen Production. Chinese Journal of Catalysis, 39, 390-394.

https://doi.org/10.1016/S1872-2067(17)62949-8

[22] Umeda, M., Sayama, K., Maruta, T. and Inoue, M. (2013) Proton Activity of Nafion 117 Membrane Measured from Potential Difference of Hydrogen Electrodes. Ionics, 19, 623-627. https://doi.org/10.1007/s11581-012-0791-Z

[23] Mališ, J., Paidar, M., Bystron, T., Brožová, L., Zhigunov, A. and Bouzek, K. (2018) Changes in Nafion 117 Internal Structure and Related Properties during Exposure to Elevated Temperature and Pressure in an Aqueous Environment. Electrochimica Acta, 262, 264-275. https://doi.org/10.1016/j.electacta.2018.01.011

[24] Vincent, I., Kruger, A. and Bessarabov, D. (2017) Development of Efficient Membrane Electrode Assembly for Low Cost Hydrogen Production by Anion Exchange Membrane Electrolysis. International Journal of Hydrogen Energy, 42, 10752 10761. https://doi.org/10.1016/j.ijhydene.2017.03.069

[25] McCrory, C.C.L., Jung, S., Ferrer, I.M., Chatman, S.M., Peters, J.C. and Jaramillo, T.F. (2015) Benchmarking Hydrogen Evolving Reaction and Oxygen Evolving Reaction Electrocatalysts for Solar Water Splitting Devices. Journal of the American Chemical Society, 137, 4347-4357. https://doi.org/10.1021/ja510442p

[26] Schalenbach, M., Carmo, M., Fritz, D.L., Mergel, J. and Stolten, D. (2013) Pressurized PEM Water Electrolysis: Efficiency and Gas Crossover. International Journal of Hydrogen Energy, 38, 14921-14933. https://doi.org/10.1016/j.ijhydene.2013.09.013

[27] Barbir, F. (2005) PEM Electrolysis for Production of Hydrogen from Renewable Energy Sources. Solar Energy, 78, 661-669. https://doi.org/10.1016/j.solener.2004.09.003

[28] Janssen, H., Bringmann, J.C., Emonts, B. and Schroeder, V. (2004) Safety-Related Studies on Hydrogen Production in High-Pressure Electrolysers. International Journal of Hydrogen Energy, 29, 759-770. https://doi.org/10.1016/j.ijhydene.2003.08.014

[29] Symes, M.D. and Cronin, L. (2013) Decoupling Hydrogen and Oxygen Evolution during Electrolytic Water Splitting Using an Electron-Coupled-Proton Buffer. Nature Chemistry, 5, 403-409. https://doi.org/10.1038/nchem.1621

[30] Wallace, A.G. and Symes, M.D. (2018) Decoupling Strategies in Electrochemical Water Splitting and Beyond. Joule, 2, 1390-1395.

https://doi.org/10.1016/j.joule.2018.06.011

[31] You, B. and Sun, Y. (2018) Innovative Strategies for Electrocatalytic Water Splitting. Accounts of Chemical Research, 51, 1571-1580. https://doi.org/10.1021/acs.accounts.8b00002

[32] Liu, X., Chi, J., Dong, B. and Sun, Y. (2019) Recent Progress in Decoupled $\mathrm{H}_{2}$ and $\mathrm{O}_{2}$ Production from Electrolytic Water Splitting. ChemElectroChem, 6, 2157-2166. https://doi.org/10.1002/celc.201801671

[33] Bergmann, H. (2021) Electrochemical Disinfection-State of the Art and Tendencies. Current Opinion in Electrochemistry, 28, Article ID: 100694. https://doi.org/10.1016/j.coelec.2021.100694

[34] Ghernaout, D. (2019) Disinfection via Electrocoagulation Process: Implied Mecha- 
nisms and Future Tendencies. EC Microbiology, 15, 79-90.

[35] Ghernaout, D. and Elboughdiri, N. (2019) Mechanistic Insight into Disinfection Using Ferrate(VI). Open Access Library Journal, 6, e5946.

[36] Ghernaout, D. and Elboughdiri, N. (2020) Disinfection By-Products (DBPs) Control Strategies in Electrodisinfection. Open Access Library Journal, 7, e6396. https://doi.org/10.4236/oalib.1106396

[37] Ghernaout, D. and Ghernaout, B. (2010) From Chemical Disinfection to Electrodisinfection: The Obligatory Itinerary? Desalination and Water Treatment, 16, 156175. https://doi.org/10.5004/dwt.2010.1085

[38] Ghernaout, D., Aichouni, M. and Touahmia, M. (2019) Mechanistic Insight into Disinfection by Electrocoagulation-A Review. Desalination and Water Treatment, 141, 68-81. https://doi.org/10.5004/dwt.2019.23457

[39] Ghernaout, D. and Elboughdiri, N. (2019) Water Disinfection: Ferrate(VI) as the Greenest Chemical-A Review. Applied Engineering, 3, 171-180.

[40] Ghernaout, D. and Elboughdiri, N. (2020) Strategies for Reducing Disinfection ByProducts Formation during Electrocoagulation. Open Access Library Journal, 7, e6076.

[41] Ghernaout, D. and Elboughdiri, N. (2020) Electrocoagulation Process in the Context of Disinfection Mechanism. Open Access Library Journal, 7, e6083.

[42] Ghernaout, D., Elboughdiri, N., Alghamdi, A. and Ghernaout, B. (2020) Trends in Decreasing Disinfection By-Products Formation during Electrochemical Technologies. Open Access Library Journal, 7, e6337. https://doi.org/10.4236/oalib.1106337

[43] Ghernaout, D. (2020) Water Treatment Challenges towards Viruses Removal. Open Access Library Journal, 7, e6408.

[44] Ghernaout, D., Touahmia, M. and Aichouni, M. (2019) Disinfecting Water: Electrocoagulation as an Efficient Process. Applied Engineering, 3, 1-12.

[45] Ghernaout, D. (2017) Microorganisms' Electrochemical Disinfection Phenomena. EC Microbiology, 9, 160-169.

[46] Bruguera-Casamada, C., Sirés, I., Prieto, M.J., Brillas, E. and Araujo, R.M. (2016) The Ability of Electrochemical Oxidation with a BDD Anode to Inactivate GramNegative and Gram-Positive Bacteria in Low Conductivity Sulfate Medium. Chemosphere, 163, 516-524. https://doi.org/10.1016/j.chemosphere.2016.08.042

[47] Yujiao, L., Ni, J. and Wang, Z. (2015) Subcellular Mechanism of Escherichia coli Inactivation during Electrochemical Disinfection with Boron-Doped Diamond Anode: A Comparative Study of Three Electrolytes. Water Research, 84, 198-206. https://doi.org/10.1016/j.watres.2015.07.035

[48] Ghernaout, D. (2019) Greening Electrocoagulation Process for Disinfecting Water. Applied Engineering, 3, 27-31.

[49] Ghernaout, D. (2019) Electrocoagulation and Electrooxidation for Disinfecting Water: New Breakthroughs and Implied Mechanisms. Applied Engineering, 3, $125-$ 133.

[50] Ghernaout, D. (2020) Electric Field (EF) in the Core of the Electrochemical (EC) Disinfection. Open Access Library Journal, 7, e6587.

[51] Ghernaout, D. (2020) Electrocoagulation as a Pioneering Separation TechnologyElectric Field Role. Open Access Library Journal, 7, e6702.

[52] Ghernaout, D. and Elboughdiri, N. (2021) Modeling Viruses' Isoelectric Points as a Milestone in Intensifying the Electrocoagulation Process for Their Elimination. Open 
Access Library Journal, 8, e7166. https://doi.org/10.4236/oalib.1107166

[53] Ghernaout, D., Alghamdi, A. and Ghernaout, B. (2019) Microorganisms' Killing: Chemical Disinfection vs. Electrodisinfection. Applied Engineering, 3, 13-19.

[54] Ghernaout, D., Badis, A., Ghernaout, B. and Kellil, A. (2008) Application of Electrocoagulation in Escherichia coli Culture and Two Surface Waters. Desalination, 219, 118-125. https://doi.org/10.1016/j.desal.2007.05.010

[55] Ghernaout, D. and Elboughdiri, N. (2019) Electrocoagulation Process Intensification for Disinfecting Water-A Review. Applied Engineering, 3, 140-147.

[56] Ghernaout, D. and Elboughdiri, N. (2019) Iron Electrocoagulation Process for Disinfecting Water-A Review. Applied Engineering, 3, 154-158.

[57] Ghernaout, D. and Elboughdiri, N. (2020) Disinfecting Water: Plasma Discharge for Removing Coronaviruses. Open Access Library Journal, 7, e6314.

https://doi.org/10.4236/oalib.1106314

[58] Ghernaout, D. (2020) Charge Neutralization in the Core of Plasma Treatment. Open Access Library Journal, 7, e6434.

[59] Matsunaga, T., Nakasono, S., Kitajima, Y. and Horiguchi, K. (1994) Electrochemical Disinfection of Bacteria in Drinking Water Using Activated Carbon Fibres. Biotechnology and Bioengineering, 43, 429-433.

https://doi.org/10.1002/bit.260430511

[60] Ghernaout, D., Elboughdiri, N. and Al Arni, S. (2020) New Insights towards Disinfecting Viruses-Short Notes. Journal of Water Reuse and Desalination, 10, 173 186. https://doi.org/10.2166/wrd.2020.050

[61] Ghernaout, D. (2019) Virus Removal by Electrocoagulation and Electrooxidation: New Findings and Future Trends. Journal of Environmental Science and Allied Research, 2019, 85-90.

[62] Ghernaout, D. (2013) Advanced Oxidation Phenomena in Electrocoagulation Process: A Myth or a Reality? Desalination and Water Treatment, 51, 7536-7554. https://doi.org/10.1080/19443994.2013.792520

[63] Ghernaout, D. and Elboughdiri, N. (2020) Advanced Oxidation Processes for Wastewater Treatment: Facts and Future Trends. Open Access Library Journal, 7, e6139.

[64] Ghernaout, D., Elboughdiri, N., Ghareba, S. and Salih, A. (2020) Electrochemical Advanced Oxidation Processes (EAOPs) for Disinfecting Water-Fresh Perspectives. Open Access Library Journal, 7, e6257. https://doi.org/10.4236/oalib.1106257

[65] Ghernaout, D., Elboughdiri, N., Ghareba, S. and Salih, A. (2020) Disinfecting Water with the Carbon Fiber-Based Flow-Through Electrode System (FES): Towards Axial Dispersion and Velocity Profile. Open Access Library Journal, 7, e6238. https://doi.org/10.4236/oalib.1106238

[66] Ghernaout, D. (2018) Electrocoagulation Process: Achievements and Green Perspectives. Colloid and Surface Science, 3, 1-5. https://doi.org/10.11648/j.css.20180301.11

[67] Rajab, M., Heim, C., Letzel, T., Drewes, J.E. and Helmreich, B. (2015) Electrochemical Disinfection Using Boron-Doped Diamond Electrode-The Synergetic Effects of in Situ Ozone and Free Chlorine Generation. Chemosphere, 121, 47-53. https://doi.org/10.1016/j.chemosphere.2014.10.075

[68] Ghernaout, D., Benblidia, C. and Khemici, F. (2015) Microalgae Removal from Ghrib Dam (Ain Defla, Algeria) Water by Electroflotation Using Stainless Steel Electrodes. Desalination and Water Treatment, 54, 3328-3337. 
https://doi.org/10.1080/19443994.2014.907749

[69] Ghernaout, D., Naceur, M.W. and Ghernaout, B. (2011) A Review of Electrocoagulation as a Promising Coagulation Process for Improved Organic and Inorganic Matters Removal by Electrophoresis and Electroflotation. Desalination and Water Treatment, 28, 287-320. https://doi.org/10.5004/dwt.2011.1493

[70] Rice, D., Westerhoff, P., Perreault, F. and García-Segura, S. (2018) Electrochemical Self-Cleaning Anodic Surfaces for Biofouling Control during Water Treatment. Electrochemistry Communications, 96, 83-87. https://doi.org/10.1016/j.elecom.2018.10.002

[71] Ghernaout, D. and Naceur, M.W. (2011) Ferrate(VI): In Situ Generation and Water Treatment-A Review. Desalination and Water Treatment, 30, 319-332. https://doi.org/10.5004/dwt.2011.2217

[72] Tsolaki, E. and Diamadopoulos, E. (2010) Technologies for Ballast Water Treatment: A Review. Journal of Chemical Technology \& Biotechnology, 85, 19-32. https://doi.org/10.1002/jctb.2276

[73] Rivas, N.G., Reyes-Perez, H. and Barrera-Diaz, C.E. (2019) Recent Advances in Water and Wastewater Electrodisinfection. ChemElectroChem, 6, 1978-1983. https://doi.org/10.1002/celc.201801746

[74] Ganiyu, S.O. and Martínez-Huitle, C.A. (2020) The Use of Renewable Energies Driving Electrochemical Technologies for Environmental Applications. Current Opinion in Electrochemistry, 22, 211-220.

https://doi.org/10.1016/j.coelec.2020.07.007

[75] Martínez-Huitle, C.A. and Brillas, E. (2008) Electrochemical Alternatives for Drinking Water Disinfection. Angewandte Chemie International Edition, 47, 1998-2005. https://doi.org/10.1002/anie.200703621

[76] Ghernaout, D. and Elboughdiri, N. (2020) Is Not It Time to Stop Using Chlorine for Treating Water? Open Access Library Journal, 7, e6007.

[77] Ghernaout, D., Naceur, M.W. and Aouabed, A. (2011) On the Dependence of Chlorine By-Products Generated Species Formation of the Electrode Material and Applied Charge during Electrochemical Water Treatment. Desalination, 270, 9-22. https://doi.org/10.1016/j.desal.2011.01.010

[78] Schaefer, C.E., Lavorgna, G.M., Webster, T.S., Deshusses, M., Andaya, C. and Urtiaga, A. (2017) Pilot-Scale Electrochemical Disinfection of Surface Water: Assessing Disinfection By-Product and Free Chlorine Formation. Water Science and Technology. Water Supply, 17, 526-536. https://doi.org/10.2166/ws.2016.165

[79] Ghernaout, D., Moulay, S., Ait Messaoudene, N., Aichouni, M., Naceur, M.W. and Boucherit, A. (2014) Coagulation and Chlorination of NOM and Algae in Water Treatment: A Review. International Journal of Environmental Monitoring and Analysis, 2, 23-34. https://doi.org/10.11648/j.ijema.s.2014020601.14

[80] Ghernaout, D. (2017) Water Treatment Chlorination: An Updated Mechanistic Insight Review. Journal of Chemical Research, 2, 125-138.

[81] Ghernaout, D., Alghamdi, A., Aichouni, M. and Touahmia, M. (2018) The Lethal Water Tri-Therapy: Chlorine, Alum, and Polyelectrolyte. World Journal of Applied Chemistry, 3, 65-71. https://doi.org/10.11648/j.wjac.20180302.14

[82] Ghernaout, D. and Elboughdiri, N. (2020) Disinfection By-Products: Presence and Elimination in Drinking Water. Open Access Library Journal, 7, e6140.

[83] Ghernaout, D. and Elboughdiri, N. (2020) Controlling Disinfection By-Products Formation in Rainwater: Technologies and Trends. Open Access Library Journal, 7, 
e6162.

[84] Sivey, J.D., McCullough, C.E. and Roberts, A.L. (2010) Chlorine Monoxide $\left(\mathrm{Cl}_{2} \mathrm{O}\right)$ and Molecular Chlorine $\left(\mathrm{Cl}_{2}\right)$ as Active Chlorinating Agents in Reaction of Dimethenamid with Aqueous Free Chlorine. Environmental Science \& Technology, 44, 3357-3362. https://doi.org/10.1021/es9038903

[85] Boucherit, A., Moulay, S., Ghernaout, D., Al-Ghonamy, A.I., Ghernaout, B., Naceur, M.W., Ait Messaoudene, N., Aichouni, M., Mahjoubi, A.A. and Elboughdiri, N.A. (2015) New Trends in Disinfection By-Products Formation upon Water Treatment. Journal of Research \& Developments in Chemistry, 2015, Article ID: 628833. https://doi.org/10.5171/2015.628833

[86] Ghernaout, D. and Elboughdiri, N. (2020) Foresight Look on the Disinfection ByProducts Formation. Open Access Library Journal, 7, e6349.

[87] Ghernaout, D. and Elboughdiri, N. (2020) Disinfection By-Products Regulation: Zero ng/L Target. Open Access Library Journal, 7, e6382.

[88] Ghernaout, D. (2020) Demobilizing Antibiotic-Resistant Bacteria and Antibiotic Resistance Genes by Electrochemical Technology: New Insights. Open Access Library Journal, 7, e6685. https://doi.org/10.4236/oalib.1106685

[89] Ghernaout, D. and Elboughdiri, N. (2020) Electrochemical Technology for Wastewater Treatment: Dares and Trends. Open Access Library Journal, 7, e6020.

[90] Ghernaout, D. and Elboughdiri, N. (2020) Towards Enhancing Ozone Diffusion for Water Disinfection-Short Notes. Open Access Library Journal, 7, e6253.

[91] Christensen, P.A., Yonar, T. and Zakaria, K. (2013) The Electrochemical Generation of Ozone: A Review. Ozone: Science \& Engineering, 35, 149-167. https://doi.org/10.1080/01919512.2012.721715

[92] Park, Y.M., Bae, M.K., Kim, J.W. and Kim, T.G. (2019) Electrochemical Oxidation of High-Concentration Ozone Generation in Flowing Water through Boron Doped Diamond Electrodes. Nanoscience and Nanotechnology Letters, 11, 1257-1262. https://doi.org/10.1166/nnl.2019.3001

[93] Lara-Ramos, J.A., Saez, C., Machuca-Martínez, F. and Rodrigo, M.A. (2020) Electro-Ozonizers: A New Approach for an Old Problem. Separation and Purification Technology, 241, Article ID: 116701. https://doi.org/10.1016/j.seppur.2020.116701

[94] Maetzke, A. and Jensen, S.J.K. (2006) Reaction Paths for Production of Singlet Oxygen from Hydrogen Peroxide and Hypochlorite. Chemical Physics Letters, 425, 40-43. https://doi.org/10.1016/j.cplett.2006.04.097

[95] Davis, J., Baygents, J.C. and Farrell, J. (2014) Understanding Persulfate Production at Boron Doped Diamond Film Anodes. Electrochimica Acta, 150, 68-74. https://doi.org/10.1016/j.electacta.2014.10.104

[96] Kim, J., Lee, C. and Yoon, J. (2018) Electrochemical Peroxodisulfate (PDS) Generation on a Self-Doped $\mathrm{TiO}_{2}$ Nanotube Array Electrode. Industrial \& Engineering Chemistry Research, 57, 11465-11471. https://doi.org/10.1021/acs.iecr.8b01208

[97] García-Segura, S., Mostafa, E. and Baltruschat, H. (2019) Electrogeneration of Inorganic Chloramines on Boron-Doped Diamond Anodes during Electrochemical Oxidation of Ammonium Chloride, Urea and Synthetic Urine Matrix. Water Research, 160, 107-117. https://doi.org/10.1016/j.watres.2019.05.046

[98] Jasper, J.T., Yang, Y. and Hoffmann, M.R. (2017) Toxic Byproduct Formation during Electrochemical Treatment of Latrine Wastewater. Environmental Science \& 
Technology, 51, 7111-7119. https://doi.org/10.1021/acs.est.7b01002

[99] Ghernaout, D. and Elboughdiri, N. (2020) Solar Treatment in the Core of the New Disinfection Technologies. Chemical Science and Engineering Research, 2, 6-11. https://doi.org/10.36686/Ariviyal.CSER.2020.02.04.014

[100] Ghernaout, D. (2018) Disinfection and DBPs Removal in Drinking Water Treatment: A Perspective for a Green Technology. International Journal of Advanced and Applied Sciences, 5, 108-117. https://doi.org/10.21833/ijaas.2018.02.018

[101] García-Segura, S., Lanzarini-Lopes, M., Hristovski, K. and Westerhoff, P. (2018) Electrocatalytic Reduction of Nitrate: Fundamentals to Full-Scale Water Treatment Applications. Applied Catalysis B: Environmental, 236, 546-568. https://doi.org/10.1016/j.apcatb.2018.05.041

[102] Ghernaout, D., Ghernaout, B. and Kellil, A. (2009) Natural Organic Matter Removal and Enhanced Coagulation as a Link between Coagulation and Electrocoagulation. Desalination and Water Treatment, 2, 203-222. https://doi.org/10.5004/dwt.2009.116

[103] Ghernaout, D. (2014) The Hydrophilic/Hydrophobic Ratio vs. Dissolved Organics Removal by Coagulation-A Review. Journal of King Saud University-Science, 26, 169-180. https://doi.org/10.1016/j.jksus.2013.09.005

[104] Ghernaout, D. and Elboughdiri, N. (2020) Eliminating Cyanobacteria and Controlling Algal Organic Matter-Short Notes. Open Access Library Journal, 7, e6252. https://doi.org/10.4236/oalib.1106252

[105] Ghernaout, D., Elboughdiri, N., Ghareba, S. and Salih, A. (2020) Coagulation Process for Removing Algae and Algal Organic Matter-An Overview. Open Access Library Journal, 7, e6272. https://doi.org/10.4236/oalib.1106272

[106] Ghernaout, D. (2020) Natural Organic Matter Removal in the Context of the Performance of Drinking Water Treatment Processes-Technical Notes. Open Access Library Journal, 7, e6751.

[107] Ghernaout, D., Badis, A., Braikia, G., Matâam, N., Fekhar, M., Ghernaout, B. and Boucherit, A. (2017) Enhanced Coagulation for Algae Removal in a Typical Algeria Water Treatment Plant. Environmental Engineering and Management Journal, 16, 2303-2315. https://doi.org/10.30638/eemj.2017.238

[108] Djezzar, S., Ghernaout, D., Cherifi, H., Alghamdi, A., Ghernaout, B. and Aichouni, M. (2018) Conventional, Enhanced, and Alkaline Coagulation for Hard Ghrib Dam (Algeria) Water. World Journal of Applied Chemistry, 3, 41-55. https://doi.org/10.11648/j.wjac.20180302.12

[109] Kellali, Y. and Ghernaout, D. (2019) Physicochemical and Algal Study of Three Dams (Algeria) and Removal of Microalgae by Enhanced Coagulation. Applied Engineering, 3, 56-64.

[110] Ghernaout, D. (2020) Enhanced Coagulation: Promising Findings and Challenges. Open Access Library Journal, 7, e6569.

[111] Ghernaout, D. and Elboughdiri, N. (2020) On the Other Side of Viruses in the Background of Water Disinfection. Open Access Library Journal, 7, e6374.

[112] Ghernaout, D. and Elboughdiri, N. (2020) Urgent Proposals for Disinfecting Hospital Wastewaters during COVID-19 Pandemic. Open Access Library Journal, 7, e6373. https://doi.org/10.4236/oalib.1106373

[113] Ghernaout, D., Ghernaout, B. and Naceur, M.W. (2011) Embodying the Chemical Water Treatment in the Green Chemistry-A Review. Desalination, 271, 1-10. https://doi.org/10.1016/j.desal.2011.01.032 
[114] Ghernaout, D. (2013) The Best Available Technology of Water/Wastewater Treatment and Seawater Desalination: Simulation of the Open Sky Seawater Distillation. Green and Sustainable Chemistry, 3, 68-88. https://doi.org/10.4236/gsc.2013.32012

[115] Ghernaout, D., Aichouni, M. and Alghamdi, A. (2018) Applying Big Data (BD) in Water Treatment Industry: A New Era of Advance. International Journal of Advanced and Applied Sciences, 5, 89-97. https://doi.org/10.21833/ijaas.2018.03.013

[116] Ghernaout, D. (2008) Élimination des substances humiques et des germes indicateurs de contamination bactériologique par électrocoagulation assistée d'un traitement magnétique de l'eau. PhD Thesis, University of Blida, Blida.

[117] Ghernaout, D. and Elboughdiri, N. (2020) Should We Forbid the Consumption of Antibiotics to Stop the Spread of Resistances in Nature? Open Access Library Journal, 7, e6138.

[118] Bergmann, H., Koparal, A.T., Koparal, A.S., Schöps, K., Iourtchouk, T. and Ehrig, F. (2008) The Influence of Products and By-Products Obtained by Drinking Water Electrolysis on Microorganisms. Microchemical Journal, 89, 98-107.

https://doi.org/10.1016/j.microc.2007.12.007

[119] Ghernaout, D. and Elboughdiri, N. (2020) Antibiotics Resistance in Water Mediums: Background, Facts, and Trends. Applied Engineering, 4, 1-6.

[120] Ghernaout, D. and Elboughdiri, N. (2020) Removing Antibiotic-Resistant Bacteria (ARB) Carrying Genes (ARGs): Challenges and Future Trends. Open Access Library Journal, 7, e6003. https://doi.org/10.4236/oalib.1106003

[121] Saha, J. and Gupta, S.K. (2017) A Novel Electro-Chlorinator Using Low Cost Graphite Electrode for Drinking Water Disinfection. Ionics, 23, 1903-1913. https://doi.org/10.1007/s11581-017-2022-0

[122] Kato, H., Hees, J., Hoffmann, R., Wolfer, M., Yang, N., Yamasaki, S. and Nebel, C.E. (2013) Diamond Foam Electrodes for Electrochemical Applications. Electrochemistry Communications, 33, 88-91. https://doi.org/10.1016/j.elecom.2013.04.028

[123] Marton, M., Vojs, M., Kotlar, M., Michniak, P., Vanco, L., Vesely, M. and Redhammer, R. (2014) Deposition of Boron Doped Diamond and Carbon Nanomaterials on Graphite Foam Electrodes. Applied Surface Science, 312, 139-144. https://doi.org/10.1016/j.apsusc.2014.05.199

[124] He, Y., Lin, H., Wang, X., Huang, W., Chen, R. and Li, H. (2016) A Hydrophobic Three-Dimensionally Networked Boron-Doped Diamond Electrode towards Electrochemical Oxidation. Chemical Communications, 52, 8026-8029. https://doi.org/10.1039/C6CC03866B

[125] Mascia, M., Monasterio, S., Vacca, A. and Palmas, S. (2016) Electrochemical Treatment of Water Containing Microcystis aeruginosa in a Fixed Bed Reactor with Three-Dimensional Conductive Diamond Anodes. Journal of Hazardous Materials, 319, 111-120. https://doi.org/10.1016/j.jhazmat.2016.03.004

[126] Azevedo, J.D., Agüera, A.L. and Lloré, P.C. (2017) Experimental Modelling of a Wide Working Range Electrochemical Water Disinfection Cell. International Journal of Engineering Research, 8, 952-958.

[127] Henquin, E.R., Colli, A.N., Bergmann, M.E.H. and Bisang, J.M. (2013) Characterization of a Bipolar Parallel-Plate Electrochemical Reactor for Water Disinfection Using Low Conductivity Drinking Water. Chemical Engineering and Processing, 65, 45-52. https://doi.org/10.1016/j.cep.2012.12.007

[128] Ghernaout, D. and Elboughdiri, N. (2020) An Insight in Electrocoagulation Process 
through Current Density Distribution (CDD). Open Access Library Journal, 7, e6142. https://doi.org/10.4236/oalib.1106142

[129] Isidro, J., Brackemeyer, D., Sáez, C., Llanos, J., Lobato, J., Cañizares, P., Matthée, T. and Rodrigo, M.A. (2020) Electro-Disinfection with BDD-Electrodes Featuring PEM Technology. Separation and Purification Technology, 248, Article ID: 117081. https://doi.org/10.1016/j.seppur.2020.117081

[130] Ghernaout, D., Alghamdi, A., Touahmia, M., Aichouni, M. and Ait Messaoudene, N. (2018) Nanotechnology Phenomena in the Light of the Solar Energy. Journal of Energy, Environmental \& Chemical Engineering, 3, 1-8. https://doi.org/10.11648/j.jeece.20180301.11

[131] Ghernaout, D., Boudjemline, A. and Elboughdiri, N. (2020) Electrochemical Engineering in the Core of the Dye-Sensitized Solar Cells (DSSCs). Open Access Library Journal, 7, e6178. https://doi.org/10.4236/oalib.1106178

[132] Boyle, C., Skillen, N., Gunaratne, H.N., Sharma, P.K., Byrne, J.A. and Robertson, P.K. (2020) The Use of Titanium Dioxide Nanotubes as Photoanodes for Chloride Oxidation. Materials Science in Semiconductor Processing, 109, Article ID: 104930. https://doi.org/10.1016/j.mssp.2020.104930

[133] Ohkouchi, Y., Yata, Y., Bun, R. and Itoh, S. (2014) Chlorine Requirement for Biologically Stable Drinking Water after Nanofiltration. Water Science and Technology: Water Supply, 14, 405-413. https://doi.org/10.2166/ws.2013.214

[134] Ghernaout, D. (2019) Reviviscence of Biological Wastewater Treatment-A Review. Applied Engineering, 3, 46-55.

[135] Ghernaout, D. and Elboughdiri, N. (2019) Upgrading Wastewater Treatment Plant to Obtain Drinking Water. Open Access Library Journal, 6, e5959.

https://doi.org/10.4236/oalib.1105959

[136] Ghernaout, D. (2018) Increasing Trends towards Drinking Water Reclamation from Treated Wastewater. World Journal of Applied Chemistry, 3, 1-9. https://doi.org/10.11648/j.wjac.20180301.11

[137] Ghernaout, D., Alshammari, Y. and Alghamdi, A. (2018) Improving Energetically Operational Procedures in Wastewater Treatment Plants. International Journal of Advanced and Applied Sciences, 5, 64-72. https://doi.org/10.21833/ijaas.2018.09.010

[138] Al Arni, S., Amous, J. and Ghernaout, D. (2019) On the Perspective of Applying of a New Method for Wastewater Treatment Technology: Modification of the Third Traditional Stage with Two Units, One by Cultivating Microalgae and Another by Solar Vaporization. International Journal of Environmental Sciences \& Natural Resources, 16, Article ID: 555934. https://doi.org/10.19080/IJESNR.2019.16.555934

[139] Ghernaout, D., Elboughdiri, N. and Ghareba, S. (2020) Fenton Technology for Wastewater Treatment: Dares and Trends. Open Access Library Journal, 7, e6045. https://doi.org/10.4236/oalib.1106045

[140] Petersen, N.B., Madsen, T., Glaring, M.A., Dobbs, F.C. and Jørgensen, N.O. (2019) Ballast Water Treatment and Bacteria: Analysis of Bacterial Activity and Diversity after Treatment of Simulated Ballast Water by Electrochlorination and UV Exposure. Science of the Total Environment, 648, 408-421. https://doi.org/10.1016/j.scitotenv.2018.08.080

[141] Ghernaout, D. and Elboughdiri, N. (2020) UV $-\mathrm{C} / \mathrm{H}_{2} \mathrm{O}_{2}$ and Sunlight $/ \mathrm{H}_{2} \mathrm{O}_{2}$ in the Core of the Best Available Technologies for Dealing with Present Dares in Domestic Wastewater Reuse. Open Access Library Journal, 7, e6161. https://doi.org/10.4236/oalib.1106161 
[142] Ghernaout, D. and Elboughdiri, N. (2020) Vacuum-UV Radiation at $185 \mathrm{~nm}$ for Disinfecting Water. Chemical Science and Engineering Research, 2, 12-17. https://doi.org/10.36686/Ariviyal.CSER.2020.02.04.015

[143] Ghernaout, D. (2019) Electrocoagulation Process for Microalgal Biotechnology-A Review. Applied Engineering, 3, 85-94.

[144] Ghernaout, D., Alghamdi, A. and Ghernaout, B. (2019) Electrocoagulation Process: A Mechanistic Review at the Dawn of Its Modeling. Journal of Environmental Science and Allied Research, 2, 51-67. https://doi.org/10.29199/2637-7063/ESAR-201019

[145] Irki, S., Ghernaout, D., Naceur, M.W., Alghamdi, A. and Aichouni, M. (2018) Decolorizing Methyl Orange by Fe-Electrocoagulation Process-A Mechanistic Insight. International Journal of Environmental Chemistry, 2, 18-28. https://doi.org/10.11648/j.ijec.20180201.14

[146] Cotillas, S., Llanos, J., Cañizares, P., Mateo, S. and Rodrigo, M. (2013) Optimization of an Integrated Electrodisinfection/Electrocoagulation Process with Al Bipolar Electrodes for Urban Wastewater Reclamation. Water Research, 50, 1741-1750. https://doi.org/10.1016/j.watres.2012.12.029

[147] Irki, S., Ghernaout, D., Naceur, M.W., Alghamdi, A. and Aichouni, M. (2018) Decolorization of Methyl Orange (MO) by Electrocoagulation (EC) Using Iron Electrodes under a Magnetic Field (MF). II. Effect of Connection Mode. World Journal of Applied Chemistry, 3, 56-64. https://doi.org/10.11648/j.wjac.20180302.13

[148] Belhout, D., Ghernaout, D., Djezzar-Douakh, S. and Kellil, A. (2010) Electrocoagulation of a Raw Water of Ghrib Dam (Algeria) in Batch Using Iron Electrodes. Desalination and Water Treatment, 16, 1-9. https://doi.org/10.5004/dwt.2010.1081

[149] Bruguera-Casamada, C., Araujo, R.M., Brillas, E. and Sirés, I. (2019) Advantages of Electro-Fenton over Electrocoagulation for Disinfection of Dairy Wastewater. Chemical Engineering Journal, 376, Article ID: 119975. https://doi.org/10.1016/j.cej.2018.09.136

[150] Robles, I., Becerra, E., Barrios, J.A., Maya, C., Jiménez, B., Rodríguez-Valadez, F.J., Rivera, F., García-Espinoza, J.D. and Godínez, L.A. (2020) Inactivation of Helminth Eggs in an Electro-Fenton Reactor: Towards Full Electrochemical Disinfection of Human Waste Using Activated Carbon. Chemosphere, 250, Article ID: 126260. https://doi.org/10.1016/j.chemosphere.2020.126260

[151] Ghernaout, D., El-Wakil, A., Alghamdi, A., Elboughdiri, N. and Mahjoubi, A. (2018) Membrane Post-Synthesis Modifications and How It Came About. International Journal of Advances in Applied Sciences, 5, 60-64. https://doi.org/10.21833/ijaas.2018.02.010

[152] Ghernaout, D. and El-Wakil, A. (2017) Requiring Reverse Osmosis Membranes Modifications-An Overview. American Journal of Chemical Engineering, 5, 81-88. https://doi.org/10.11648/j.ajche.20170504.15

[153] Ghernaout, D. (2017) Reverse Osmosis Process Membranes Modeling-A Historical Overview. Journal of Civil, Construction and Environmental Engineering, 2, 112-122.

[154] Ghernaout, D., Alshammari, Y., Alghamdi, A., Aichouni, M., Touahmia, M. and Ait Messaoudene, N. (2018) Water Reuse: Extenuating Membrane Fouling in Membrane Processes. International Journal of Environmental Chemistry, 2, 1-12. https://doi.org/10.11648/j.ajche.20180602.12

[155] Ghernaout, D. (2019) Brine Recycling: Towards Membrane Processes as the Best Available Technology. Applied Engineering, 3, 71-84. 
[156] Khan, M.I., Shanableh, A., Elboughdiri, N., Kriaa, K., Ghernaout, D., Ghareba, S., Khraisheh, M. and Lashari, M.H. (2021) Higher Acid Recovery Efficiency of Novel Functionalized Inorganic/Organic Composite Anion Exchange Membranes from Acidic Wastewater. Membranes, 11, 133. https://doi.org/10.3390/membranes11020133

[157] Ghernaout, D. (2020) New Configurations and Techniques for Controlling Membrane Bioreactor (MBR) Fouling. Open Access Library Journal, 7, e6579.

[158] Ait Messaoudene, N., Naceur, M.W., Ghernaout, D., Alghamdi, A. and Aichouni, M. (2018) On the Validation Perspectives of the Proposed Novel Dimensionless Fouling Index. International Journal of Advanced and Applied Sciences, 5, 116-122. https://doi.org/10.21833/ijaas.2018.07.014

[159] Tan, X., Chen, C., Hu, Y., Wen, J., Qin, Y., Cheng, J. and Chen, Y. (2018) Novel AgNWs-Pan/TPU Membrane for Point-of-Use Drinking Water Electrochemical Disinfection. Science of the Total Environment, 638, 408-417. https://doi.org/10.1016/j.scitotenv.2018.05.012

[160] Liang, S., Lin, H., Habteselassie, M. and Huang, Q. (2018) Electrochemical Inactivation of Bacteria with a Titanium Sub-Oxide Reactive Membrane. Water Research, 145, 172-180. https://doi.org/10.1016/j.watres.2018.08.010

[161] Laxman, K., Myint, M.T.Z., Al Abri, M., Sathe, P., Dobretsov, S. and Dutta, J. (2015) Desalination and Disinfection of Inland Brackish Ground Water in a Capacitive Deionization Cell Using Nanoporous Activated Carbon Cloth Electrodes. Desalination, 36, 126-132. https://doi.org/10.1016/j.desal.2015.02.010

[162] Rogers, T.W., Rogers, T.S., Stoner, M.H., Sellgren, K.L., Lynch, B.J., Forbis-Stokes, A.A., Stoner, B.R. and Hawkins, B.T. (2018) A Granular Activated Carbon/Electrochemical Hybrid System for Onsite Treatment and Reuse of Blackwater. Water Research, 144, 553-560. https://doi.org/10.1016/j.watres.2018.07.070

[163] Hussain, S.N., Trzcinski, A.P., Asghar, H.M.A., Sattar, H., Brown, N.W. and Roberts, E.P.L. (2016) Disinfection Performance of Adsorption Using Graphite Adsorbent Coupled with Electrochemical Regeneration for Various Microorganisms Present in Water. Journal of Industrial and Engineering Chemistry, 44, 216-225. https://doi.org/10.1016/j.jiec.2016.09.009

[164] Denisova, V. and Mezule, L. (2019) Electrochemical/Granular Activated Carbon Hybrid System for Drinking Water Disinfection at Flow Conditions. Chemical Engineering Transactions, 74, 1303-1308.

[165] Egerton, T.A., Christensen, P.A., Kosa, S.A.M., Onoka, B., Harper, J.C. and Tinlin, J.R. (2006) Photoelectrocatalysis by Titanium Dioxide for Water Treatment. International Journal of Environment and Pollution, 27, 2-19. https://doi.org/10.1504/IJEP.2006.010450

[166] Daghrir, R., Drogui, P. and Robert, D. (2012) Photoelectrocatalytic Technologies for Environmental Applications. Journal of Photochemistry and Photobiology A, 238, 41-52. https://doi.org/10.1016/j.jphotochem.2012.04.009

[167] De Araújo, D.M., Sáez, C., Cañizares, P., Rodrigo, M.A. and Martínez-Huitle, C.A. (2018) Improving the Catalytic Effect of Peroxodisulfate and Peroxodiphosphate Electrochemically Generated at Diamond Electrode by Activation with Light Irradiation. Chemosphere, 207, 774-780.

https://doi.org/10.1016/j.chemosphere.2018.05.121 